\title{
ANALISA EKONOMIS PERALATAN PULVERIZER UNTUK OPTIMALISASI KEANDALAN PLTU DENGAN SIMULASI MONTE CARLO DAN PENDEKATAN ANALISA BIAYA SIKLUS HIDUP (Studi Kasus: PLTU X)
}

\author{
Reza Firdian Mardiansyah ${ }^{1)}$, Elisa Kusrini ${ }^{2)}$, Faisal RM ${ }^{3)}$ \\ Magister Teknik Industri, Fakultas Teknologi Industri, Universitas Islam Indonesia ${ }^{1,2,3)}$ \\ Jl. Kaliurang Km 14,5 Sleman Yogyakarta, 55584 \\ Email:ferdian.85211@gmail.com ${ }^{1)}$,elisakusrini@uii.ac.id ${ }^{2}$,faisal.rm@uii.ac.id ${ }^{3)}$
}

\begin{abstract}
To improve and maintain the reliability of PLTU X (FTP-1) power supply using coal fuel it is necessary to improve the reliability of the equipment especially on the crucial equipment which one of the pulverizer equipment for it is necessary to process the procurement of equipment components (stock warehouse) to maintain if possible a malfunction or malfunction occurs. The author intends to make three alternative procurement process that is through OEM procurement process, Non OEM / reverse engineering and recondition.

This journal will analyze a financial feasibility study to ascertain whether the procurement has economic value and the asset will be used effectively and efficiently over the life of the benefit using the LCCA cost analysis approach. In this paper, historical data on pulverizer damage is obtained from the HDKP Rapsodi Settlement application to be verified and processed using minitab 17 applications to obtain the weibull shape factor $(\beta)$ and scale factor / characteristic life $(\eta)$ and the data as monte carlo simulation input. So we get mean time to failure (MTTF) / age of pulverizer component. To analyze the three alternatives and determine which alternatives are most profitable for 10 years with a life cycle cost analysis approach.

Based on the analysis of quantitative calculation data, the life of pulverizer mills (MTTF) procurement process OEM for 10,108 hours / 1.2 years, non-OEM / reverse engineering for 16,899 hours / 2 years and recondition for 5,323 hours / 0.7 years and the results of approach life cycle cost analysis was obtained cost savings of 35.22 billion per unit pulverizer mills for 10 years with reverse engineering procurement process compared to OEM.
\end{abstract}

Keywords : Pulverizer, Mean Time To Failure, Cost Life Cycle Analysis.

\section{PENDAHULUAN}

PLTU X merupakan pembangkit listrik dengan menggunakan bahan bakar batubara yang digunakan untuk memanaskan boiler untuk megubah air menjadi uap bertekanan. Pada boiler sendiri terdapat empat pulverizer yang berfungsi / beroperasi untuk menghaluskan batubara sebelum masuk boiler. Untuk menjamin sistem pembangkit dapat beroperasi secara kontinyu, biasanya dipasang satu standby pulverizer untuk menggantikan fungsi pulverizer yang mengalami kerusakan sedangkan pendapat (Ratna Bhakti dan Sudiyono K, 2015) beberapa sub-sistem pulverizer sering mengalami kerusakan yang dapat menimbulkan kegagalan pada sistem tersebut maka membuat perencanaan pemeliharaan menggunakan metode Reliability Centered Maintenance (RCM) pada pulverizer untuk menurunkan tingkat breakdown mesin dan downtime produksi dengan identifikasi FMEA terdapat 12 failure mode yang terjadi dipulverizer termasuk penelitian (Rio Prasetyo Lukodono et al, 2013) menggunakan Reliability Centered Maintenance (RCM) dan Maintenance Value Stream Mapping (MVSM) untuk meningkatkan keandalan pada sistem maintenance dan penelitian (Umi Fitriyani, 2011) menentukan waktu perawatan pulverizer menggunakan metode RCM II 
dengan pendekatan Benefit - Cost Analysis untuk menilai risiko kegagalan fungsi yang timbul oleh mesin pulverizer mill terdapat 15 kegagalan. Menurut penelitian (Herry Nugraha et al, 2016) menerapkan Reliability, Availability, Maintainability and Security (RAMS) dengan menggunakan simulasi Monte Carlo dan mengukur efektifitas biaya dengan menggunakan Life Cycle Cost Analysis (LCCA) untuk pemilihan alternatif pemeliharaan pada kabel laut transmisi jawabali $150 \mathrm{kV}$ dan juga penelitian (Ngapuli I. Sinisuka et al, 2013) menerapkan Life Cycle Cost Analysis (LCCA) pada operasi pembangkit listrik dengan menghitung seluruh biaya determistik dan biaya probabilistik dengan studi kasus PLTU 330 MW untuk mendapatkan menilai program manajemen yang efektif dengan biaya resiko rendah sedangkan penelitian (Weta Hary W et al, 2013) menganalisa keandalan dengan menggunakan Failure Mode and Effect Analysis (FMEA) sedangkan artikel dari (Winda Nur Cahyo, 2008) pendekatan simulasi monte carlo untuk memilih alternatif dengan decision tree pada nilai outcome yang probabilistik.

Data ganguan pembangkit PLTU X (FTP-1) didapatkan dari aplikasi rapsodi HDKP setelmen, pembangkit ini aset ownernya PT PLN (Persero) Regional Jawa Bagian Tengah yang dikendalikan sebagai aset manajer dan aset operasi oleh anak perusahaan PT Pembangkitan Jawa Bali masih di dapat temuan masalah antaranya :

1. Sering mengalami kerusakan yang tidak terencana.

2. Umur pengoperasian lebih pendek dari desain.

3. Tidak dapat operasi secara maksimal.

4. Batubara tidak hancur secara sempurna.

5. Proses pengadaan lama dalam mendapatkan material tersebut.

6. Kualitas yang didapatkan tidak sesuai dengan yang diharapkan.
Pada kondisi sekarang ini bila terjadi kerusakan pada komponen pulverizer baru mengusulkan dengan dilakukan eksekusi dengan berbagai cara perbaikan dan juga pembelian sehingga perencanaan dan kajian kurang efisien waktu, biaya dan kesiapan operasi. Untuk itu belum ada metode optimum untuk pemilihan alternatif.

Oleh karena itu, peneliti mencoba membuatkan dan mengimplementasi suatu metode penelitian ini dengan pendekatan simulasi Monte Carlo dan pendekatan analisa biaya siklus hidup (LCCA) untuk mengoptimalkan resiko, biaya dan kinerja pembangkit terhadap komponen peralatan pulverizer. Hasil akhir dari analisis ini adalah memberikan masukan kepada manajemen dari beberapa alternatif diantaranya pengadaan OEM, pengadaan non OEM dan rekondisi yang mana perhitungan tersebut memberikan masukan untuk dalam memberikan keputusan yang tepat sesuai dengan prediksi sehingga mendapatkan pilihan optimal.

Dengan melihat kompeksnya permasalahan yang ada, maka pembatasan masalah dilakukan sebagai berikut :

1. Pengambil data sekunder dari aplikasi rapsodi HDKP Setelment PLTU X kemudian dimasukan kedalam aplikasi minitab 17.

2. Salah satu komponen vital mill pulverizer adalah mill termasuk table.

3. Perhitungan dengan menggunakan Life Cycle Cost Analysis (LCCA). Dengan LCCA pada komponen pulverizer level 2 terdiri dari feeder, motors and drives, mills, mill coal level controls, coal leak, control system, other pulverizer problems dan inspection.

4. Keputusan optimal dapat diambil berdasarkan analisis ekonomi yang memperhitungkan total biaya coal mill pulverizer tersebut. 


\section{TINJAUAN PUSTAKA}

Manajemen Aset memiliki pengertian sebagai kegiatan dan praktik yang sistematis dan terkoodinir dari organisasi dalam mengelola aset dan sistem asetnya secara berkesinambungan dengan mengoptimalkan kinerja, risiko dan biaya pada siklus hidup asetnya yang bertujuan untuk mencapai rencana strategis perusahaan (Iwan Agung Firstantara, 2014).

Simulasi adalah sebuah metode analitik yang bertujuan untuk membuat "imitasi" dari sebuah sistem yang mempunyai sifat acak, dimana jika digunkan model lain menjadi sangat mathematically complex atau terlalu sulit untuk dikembangkan. Simulasi Monte Carlo adalah salah satu metode simulasi sederhana yang dapat dibangun secara cepat dengan hanya menggunakan spreadsheet $M S$ Excell (Winda Nur Cahyo, 2008).

Mean Time To Failure (MTTF) dihitung dengan menggunakan simulasi Monte Carlo berdasarkan nilai Weibull Shape Factor $(\beta)$ dan Weibull Characteristic Life ( $\eta$ ) untuk setiap sub-sistem. Waktu kegagalan $\mathrm{T}_{\mathrm{F}}$ adalah fungsi dari kriteria nilai kegagalan $F_{(t)}$. Persamaan untuk menghitung $\mathrm{T}_{\mathrm{F}}$ dan MTTF adalah :

$$
\begin{gathered}
T_{F}=\eta[-\ln (1-F(t))]^{\frac{1}{\beta}} \ldots \\
M T T F_{\text {sub-sistem }}=\frac{\sum T_{A T T F}}{\sum T_{F}}
\end{gathered}
$$

Dimana $\mathrm{T}_{\mathrm{ATTF}}$ (Total Accumulation of Time To Failure).
Penjelasan keputusan nilai yang didapatkan 1 jika RAND () $>\mathrm{T}_{\mathrm{F}}$ nilai kegagalan adalah 0 atau akan memberikan nilai acak distribusi normal tingkat kegagalan bervariasi antara 0 dan 1. Selama perhitungan simulasi Monte Carlo, nilai $\mathrm{T}_{\mathrm{F}}$ dan MTTF selalu berubah sesuai dengan angka acak $\mathrm{F}_{(\mathrm{t})}$ $=$ RAND () yang dihasilkan oleh komputer (Ngapuli I. Sinisuka et al, 2013).

Rumusan umum perhitungan LCC atas suatu sistem / sub-sistem adalah sebagaimana persamaan (Jianpeng Bian et al, 2014),

$L C C=C I+C O+C M+C F+C D$

LCC dimana masing - masing komponennya adalah sebagai berikut:

CI : Biaya Investasi.

$\mathrm{CO}$ : Biaya Operasi.

$\mathrm{CM}$ : Biaya Pemeliharaan.

CF : Biaya Atas Kerusakan.

CD : Biaya Atas Tahap Disposal.

\section{METODOLOGI PENELITIAN}

Penelitian ini dilakukan dari studi literatur dan studi lapangan untuk mengetahui kondisi peralatan pulverizer sehingga didapatkan data pendukung penelitian dari tahun Comercial of Date (COD) / mulai operasi komersial tahun 2011 sampai tahun 2017, selanjutnya dilakukan verifikasi perkomponen pulverizer dan diolah dengan menggunakan aplikasi minitab 17 untuk mendapatkan weibull shape factor $(\beta)$ dan weibull scale factor / characteristic life

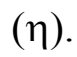


Kemudian dimasukan kedalam simulasi monte carlo untuk mendapatkan Mean Time To Failure (MTTF) perkomponen pulverizer, khusus pulverizer mills di-breakdown berdasarkan kondisi OEM, RE dan Rekondisi. Selanjutnya pengelolahan data tahap dua menghitung seluruh biaya berdasarkan alternatif sesuai pendekatan analisa biaya siklus hidup (LCCA). Didapatkan hasil analisa titik impas, analisa sensitivitas, total biaya dan keuntungan akibat avoide cost.

\section{HASIL DAN PEMBAHASAN \\ 4.1 Deskripsi Komponen Pulverizer}

Setelah dilakukan verifikasi data gangguan komponen pulverizer sesuai kode gangguan di-level 2 mengacuh pedoman (PT PLN (Persero), 2017) didapatkan dari aplikasi rapsodi HDKP. Kemudian di hitung gangguan satu dengan gangguan kedua dengan lokasi sama pada komponen pulverizer / mencari time between failure (TBF). Kemudian dikompokan berdasarkan berdasarkan tiga alternatif dimana info dari aset operator di lapangan bahwa reverse engineering umur aset lebih lama dibandingkan pulverizer original (OEM) dan rekondisi, sehingga di ambil data berdasarkan tingkat tertinggi reverse engineering, kedua OEM dan ketiga rekondisi didapatkan hasil sesuai tabel 1.

Setelah didapatkan data time between failure dari OEM, RE dan rekondisi kemudian di input kedalam aplikasi minitab 17 untuk mendapatkan weibull shape factor $(\beta)$ dan scale factor/ characteristic life $(\eta)$ dapat di lihat sesuai gambar 2 .

Dan dilakukan lagi satu persatu langkanya dari awal laporan gangguan perkomponen sampai didapatkan makan didapatkan shape factor $(\beta)$ dan scale factor/ characteristic life $(\eta)$ sesuai data tabel 2.

\subsection{Hasil Simulasi Monte Carlo}

Dari tabel 2 atas didapatkan weibull shape factor ( $\beta$ ) dan scale factor/ characteristic life ( $\eta$ ) masing - masing komponen kemudian dimasukan kedalam simulasi monte carlo dengan dilakukan 5.000 kali percobaan untuk mendapatkan mean time between failure (MTTF) per komponen, khusus pulverizer mills di-breakdown berdasarkan kondisi OEM, RE dan Rekondisi.

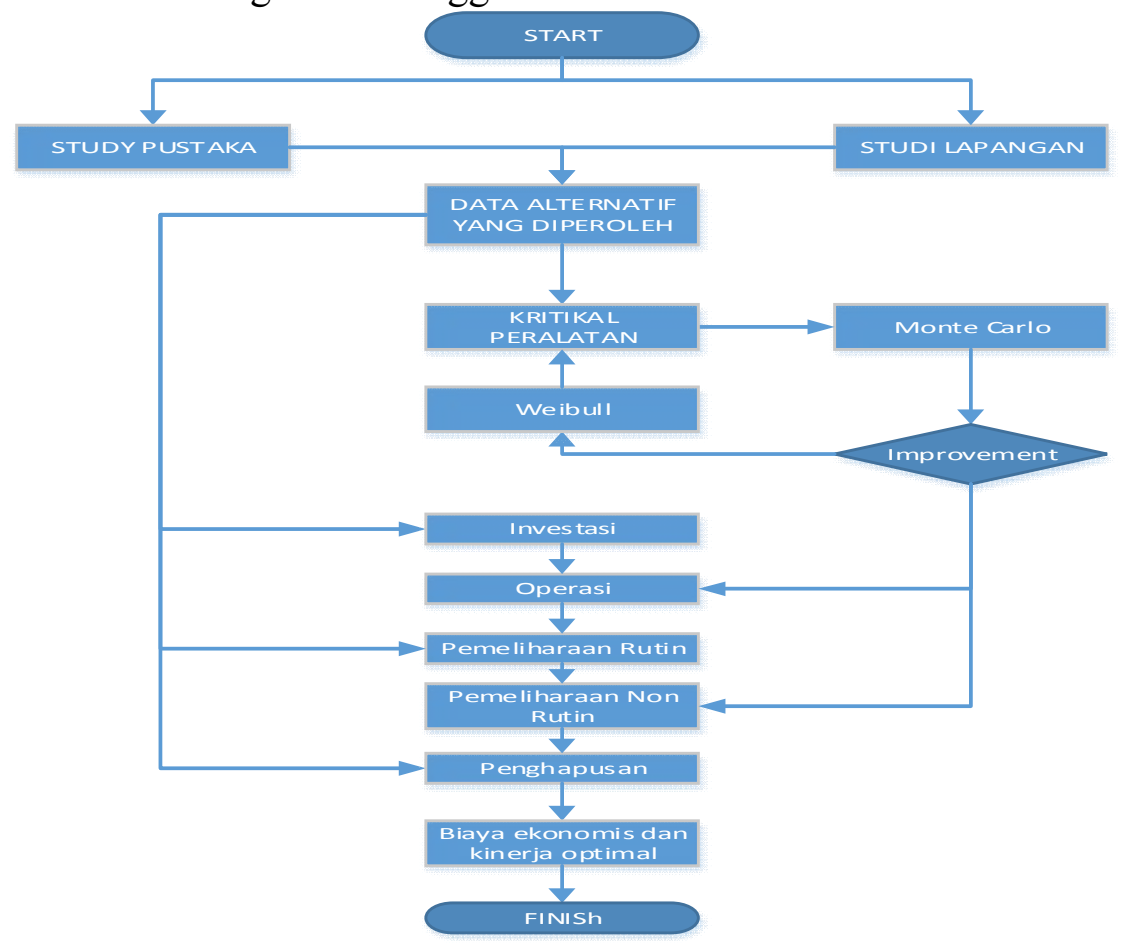

Gambar 1. Diagram Alur Metode Penelitian. 
Tabel 1. Data Rekap Time Between Failure (TBF) Pulverizer Mills

\begin{tabular}{c|c|c|c|c|c|c|c|c|c|c|c|c|c}
\hline \multirow{2}{*}{ No. } & \multicolumn{9}{c|}{ Unit 1 } & \multicolumn{7}{c|}{ Unit 2 } & \multicolumn{3}{c}{$\begin{array}{c}\text { Hasil Verifikasi Data } \\
\text { TBF }\end{array}$} \\
\cline { 2 - 13 } & $\mathbf{A}$ & $\mathbf{B}$ & $\mathbf{C}$ & $\mathbf{D}$ & $\mathbf{E}$ & $\mathbf{A}$ & $\mathbf{B}$ & $\mathbf{C}$ & $\mathbf{D}$ & $\mathbf{E}$ & OEM & RE & $\begin{array}{c}\text { Rekon } \\
\text { disi }\end{array}$ \\
\hline 1 & 3.298 & 1.906 & 13.584 & 3.897 & 3.897 & 4.650 & 2.240 & 4.856 & 2.240 & 5.833 & 14.089 & 33.952 & 3.298 \\
2 & 14.089 & 3.492 & 14.405 & 461 & 575 & 8.655 & 4.107 & 7.273 & 2.210 & 8.680 & 11.759 & 34.669 & 3.492 \\
3 & 717 & 405 & 156 & 114 & 224 & 18.090 & 7.028 & 4.561 & 200 & 4 & 14.405 & 23.911 & 13.584 \\
4 & 33.952 & 576 & 23.911 & 8.399 & 8.175 & 5.161 & 173 & 16.884 & 206 & 144 & 8.399 & 38.472 & 3.897 \\
5 & & 414 & & 576 & 39.185 & 1.917 & 29.512 & 18.482 & 1.491 & 26.009 & 8.175 & 39.185 & 3.897 \\
6 & & 742 & & 138 & & 20.661 & 8.996 & & 5.782 & 1.719 & 18.090 & 20.661 & 8.655 \\
7 & & 11.759 & & 38.472 & & & & & 1.176 & 1.917 & 8.996 & 29.512 & 7.028 \\
8 & & 34.669 & & & & & & & 3.385 & 4.785 & 16.884 & 18.482 & 7.273 \\
9 & & & & & & & & & 14.704 & 8.798 & 14.704 & 20.661 & 5.782 \\
10 & & & & & & & & & 20.661 & & 8.798 & 26.009 & 8.680 \\
\hline
\end{tabular}

Tabel 2. Data Hasil Aplikasi Minitab 17

\begin{tabular}{c|l|c|c|c|c|c|c}
\hline \multirow{2}{*}{ No. Komponen } & \multicolumn{2}{|c|}{ Alternatif OEM } & \multicolumn{2}{c|}{ Alternatif RE } & \multicolumn{2}{c}{$\begin{array}{c}\text { Alternatif } \\
\text { Rekondisi }\end{array}$} \\
\cline { 3 - 8 } & & $\boldsymbol{\beta}$ & $\boldsymbol{\eta}$ & $\boldsymbol{\beta}$ & $\boldsymbol{\eta}$ & $\boldsymbol{\beta}$ & $\boldsymbol{\eta}$ \\
\hline 1 & Pulverizer Feeder & 0,7 & 9,962 & 0,7 & 9,962 & 0,7 & 9,962 \\
2 & Pulverizer Motors and Drives & 4,5 & 47,883 & 4,5 & 47,883 & 4,5 & 47,883 \\
3 & Pulverizer Mills & 4,0 & 13,759 & 4,4 & 31,400 & 2,3 & 7,438 \\
4 & Pulverizer Mills Coal Level Controls & 4,5 & 47,880 & 4,5 & 47,880 & 4,5 & 47,880 \\
5 & Pulverizer Coal Leak & 1,3 & 39,201 & 1,3 & 39,201 & 1,3 & 39,201 \\
6 & Pulverizer Control System & 2,5 & 29,522 & 2,5 & 29,522 & 2,5 & 29,522 \\
7 & Other Pulverizer Problems & 0,9 & 16,580 & 0,9 & 16,580 & 0,9 & 16,580 \\
8 & Pulverizer Inspection & 2,1 & 47,226 & 2,1 & 47,226 & 2,1 & 47,226 \\
\hline
\end{tabular}

Tabel 3. Data Mean Time To Failure (MTTF) OEM, Reverse Engineering, Rekondisi

\begin{tabular}{|c|c|c|c|c|c|c|c|}
\hline \multicolumn{4}{|c|}{ Simulation Data Random } & \multicolumn{4}{|c|}{ Simulation Result } \\
\hline Sub System & $\boldsymbol{\beta}$ & $\eta$ & $F(t)=R A N D 0$ & $T_{g}=\eta[-\ln (1-f(t))]$ & $\begin{array}{c}\text { Total \# } \\
\text { Failures } \\
\text { Simulated }\end{array}$ & $\begin{array}{c}\text { Total } \\
\text { Accumulated } \\
\text { Time For } \\
\text { Failures } \\
\end{array}$ & $\begin{array}{l}\text { Mean } \\
\text { time to } \\
\text { failure }\end{array}$ \\
\hline Pulverizer Feeder & 0,7 & 9,962 & 0,350 & 3,087 & 2,528 & $7,510,131$ & 2,971 \\
\hline Pulverizer Motors and Drives & 4,4 & 47,883 & 0,462 & 43,081 & 2 & 12,265 & 6,132 \\
\hline Pulverizer Mills & 2,3 & 13,759 & 0,548 & 12,986 & 562 & $5,680,532$ & 10,108 \\
\hline $\begin{array}{l}\text { Pulverizer Mills Coal Level } \\
\text { Controls }\end{array}$ & 4,6 & 47,880 & 0,634 & 47,947 & 1 & 4,725 & 4,725 \\
\hline Pulverizer Coal Leak & 1,3 & 39,201 & 0,081 & 5,909 & 362 & $1,883,716$ & 5,204 \\
\hline Pulverizer Control System & 2,5 & 29,522 & 0,753 & 33,693 & 118 & 946,816 & 8,024 \\
\hline Other Pulverizer Problems & 0,9 & 16,580 & 0,189 & 2,964 & 1,378 & $5,197,434$ & 3,772 \\
\hline Pulverizer Inspection & 2,1 & 47,226 & 0,862 & 65,287 & 53 & 364,254 & 6,873 \\
\hline & & & & 2,694 & 5,004 & $21,599,873$ & \\
\hline
\end{tabular}




\begin{tabular}{|c|c|c|c|c|c|c|c|}
\hline \multicolumn{4}{|c|}{ Simulation Data Random } & \multicolumn{4}{|c|}{ Simulation Result } \\
\hline Sub System & $\boldsymbol{\beta}$ & $\eta$ & $F(t)=R A N D O$ & $P=\eta[-\ln (1-f(t))]^{\frac{1}{3}}$ & $\begin{array}{c}\text { Total \# } \\
\text { Failures } \\
\text { Simulated }\end{array}$ & $\begin{array}{c}\text { Total } \\
\text { Accumulated } \\
\text { Time For } \\
\text { Failures } \\
\end{array}$ & $\begin{array}{l}\text { Mean } \\
\text { time to } \\
\text { failure }\end{array}$ \\
\hline Pulverizer Feeder & 0,7 & 9,962 & 0,685 & 12,194 & 2,700 & $10,176,247$ & 3,769 \\
\hline Pulverizer Motors and Drives & 4,4 & 47,883 & 0,992 & 67,684 & 10 & 156,057 & 15,606 \\
\hline Pulverizer Mills & 2,3 & 31,400 & 0,566 & 30,154 & 53 & 895,624 & 16,899 \\
\hline $\begin{array}{l}\text { Pulverizer Mills Coal Level } \\
\text { Controls }\end{array}$ & 4,6 & 47,880 & 0,540 & 45,312 & 8 & 120,125 & 15,016 \\
\hline Pulverizer Coal Leak & 1,3 & 39,201 & 0,830 & 60,772 & 365 & $2,573,785$ & 7,051 \\
\hline Pulverizer Control System & 2,5 & 29,522 & 0,277 & 18,946 & 204 & $2,311,954$ & 11,333 \\
\hline Other Pulverizer Problems & 0,9 & 16,580 & 0,213 & 3,442 & 1,586 & $7,538,261$ & 4,753 \\
\hline Pulverizer Inspection & 2,1 & 47,226 & 0,948 & 78,881 & 76 & 756,640 & 9,956 \\
\hline & & & & 2,442 & 5,002 & $24,528,695$ & \\
\hline
\end{tabular}

\begin{tabular}{|c|c|c|c|c|c|c|c|}
\hline \multicolumn{4}{|c|}{ Simulation Data Random } & \multicolumn{4}{|c|}{ Simulation Result } \\
\hline Sub System & $\boldsymbol{\beta}$ & $\eta$ & $F(t)=R A N D 0$ & $\eta_{g}=\eta[-\ln (1-f(t))]^{1}$ & $\begin{array}{c}\text { Total \# } \\
\text { Failures } \\
\text { Simulated }\end{array}$ & $\begin{array}{c}\text { Total } \\
\text { Accumulated } \\
\text { Time For } \\
\text { Failures } \\
\end{array}$ & $\begin{array}{c}\text { Mean } \\
\text { time to } \\
\text { failure }\end{array}$ \\
\hline Pulverizer Feeder & 0,7 & 9,962 & 0,136 & 692 & 2,087 & $4,424,882$ & 2,120 \\
\hline Pulverizer Motors and Drives & 4,4 & 47,883 & 0,763 & 51,904 & 0 & 0 & \#DIV/0! \\
\hline Pulverizer Mills & 2,3 & 7,348 & 0,091 & 2,667 & 1,541 & $8,061,865$ & 5,232 \\
\hline $\begin{array}{l}\text { Pulverizer Mills Coal Level } \\
\text { Controls }\end{array}$ & 4,6 & 47,880 & 0,611 & 47,279 & 0 & 0 & \#DIV/0! \\
\hline Pulverizer Coal Leak & 1,3 & 39,201 & 0,658 & 41,387 & 231 & 771,027 & 3,338 \\
\hline Pulverizer Control System & 2,5 & 29,522 & 0,078 & 10,975 & 63 & 379,460 & 6,023 \\
\hline Other Pulverizer Problems & 0,9 & 16,580 & 0,766 & 24,999 & 1,051 & $2,731,842$ & 2,599 \\
\hline Pulverizer Inspection & 2,1 & 47,226 & 0,276 & 27,639 & 31 & 136,738 & 4,411 \\
\hline & & & & 692 & 5,004 & $16,505,814$ & \\
\hline
\end{tabular}

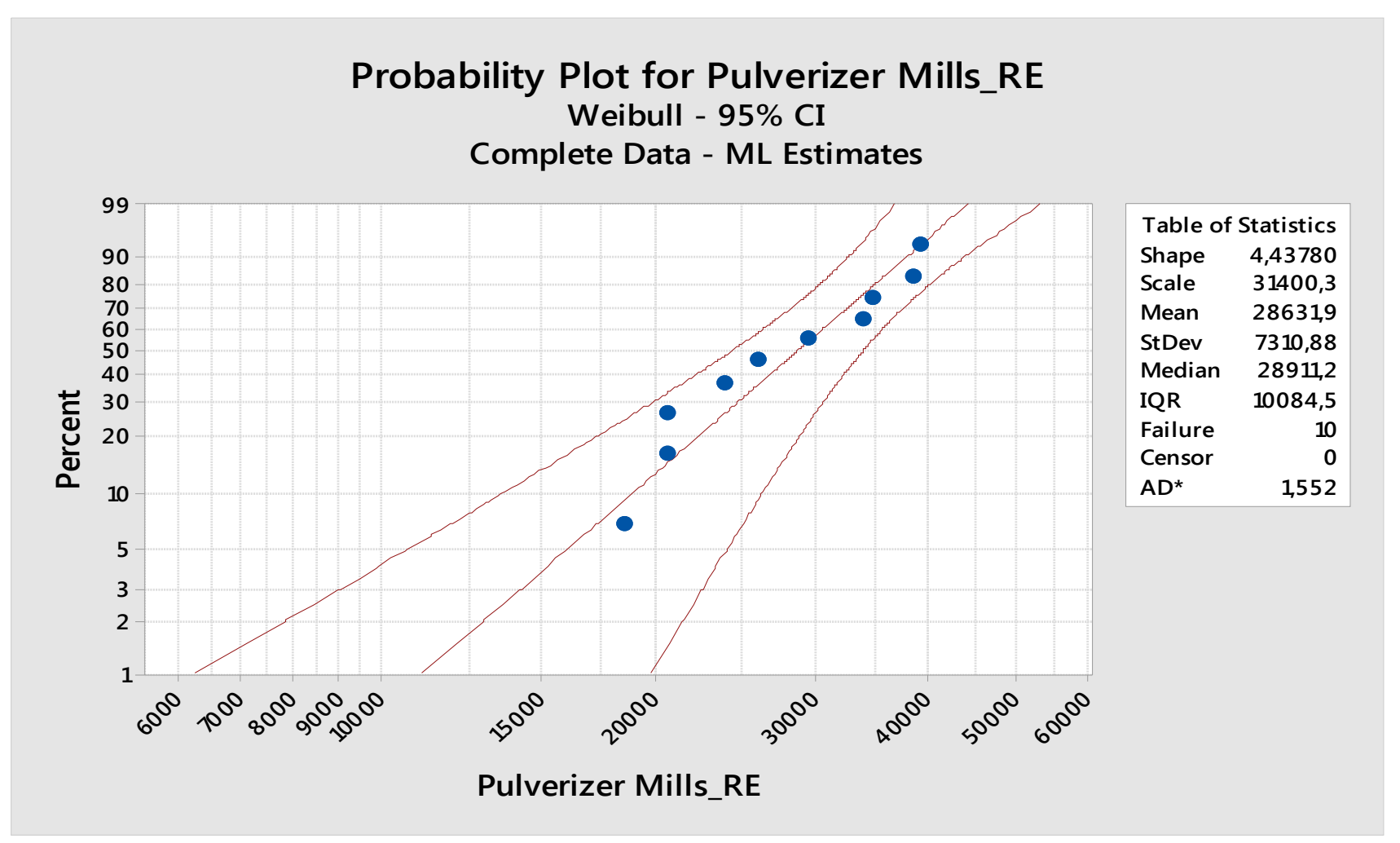

Gambar 2. Grafik $\beta$ dan $\eta$ Pulverizer Mills RE. 
Dari tabel 3 diatas didapatkan MTTF proses pengadaan OEM sebesar 10.108 jam, proses pengadaan reverse engineering sebesar 16.899 jam dan proses pengadaan rekondisi sebesar 5.232 jam.

\subsection{Cost Benefit Analyst Menghindari Avoide Cost}

Asumsi :

Batubara satu jam $\quad=30.000 \mathrm{~kg}$.

Gross Plant Heat Rate $=2.751 \mathrm{kCal} / \mathrm{kWH}$.

Nilai Kalori Batubara $=4.200 \mathrm{kCal} / \mathrm{kg}$.

Harga komponen $\mathrm{C}=\mathrm{Rp} 321 / \mathrm{kWH}$.

(PLTU Rembang November 2017).

Harga komponen $\mathrm{C}=\mathrm{Rp} 356 / \mathrm{kWH}$.

(PLTU TJB November 2017).

Efisiensi pulverizer $\quad=90 \%$.

Didapatkan :

BPP pengganti $=356-321$.

$$
=\mathrm{Rp} .35 / \mathrm{kWH} \text {. }
$$

Produksi per jam $=(4.200 \times 30.000 \times 90 \%) /$ $2.75=41.221,-\mathrm{kWH}$.

Harga per bulan = harga jual $\mathrm{x}$ produksi $\mathrm{x}$ bulan

$$
\begin{aligned}
& =35 \times 41.221 \times 24 \times 30 . \\
& =\operatorname{Rp} 1.038 .778 .626 .
\end{aligned}
$$

\subsection{Proses Pengadaan OEM}

Asumsi :

1 Mill ada 3 grinding roll = Rp. 594.248.070.

1 Set grinding table = Rp. 145.774.812 .

(PT PJB STOCKIST)

Biaya bongkar pasang $=$ Rp. 38.500.000.

(data maximo)

Biaya sewa alat $\quad=$ Rp. 2.200.000.

(data maximo)

Biaya comsumable $=$ Rp. 950.000 .

(data maximo)

Waktu pemesanan $=8$ bulan.

Waktu pemasangan $\mathrm{CM} \quad=63$ hari.

(sama dengan Serious Inspection awal)

Umur Grinding roll $\quad=10.108$ jam.

Pinjaman Bank Setahun $=90 \%$.

Proporsi pendanaan dari Bank

Bunga Bank se tahun $=18,75 \%$ dan

Deposito $\quad=5 \%$.

$\begin{array}{ll}\text { WACC didapat } & =17,38 \% . \\ \text { PPN } & =10 \% . \\ \text { PPH Badan } & =25 \% .\end{array}$

Perhitungan disamakan dalam penyebutan KPK dari 3 alternatif berdasarkan umur aset untuk OEM didapatkan 1,18 dibuatkan perhitungan ke profil analisa biaya siklus hidup (LCCA) untuk proses pengadaan OEM didapatkan sesuai tabel 4.

\subsection{Proses Pengadaan Reverse \\ Engineering} Asumsi :

1 Mill ada 3 grinding roll $=\mathrm{Rp} .324 .510 .000$.

1 Set grinding table = Rp. 85.000.000.

(PT HANSA)

Waktu pemesanan $\quad=6$ bulan.

Umur Grinding roll $=16.899$ jam $=2$ tahun.

Perhitungan disamakan dari 3 alternatif dalam penyebutan KPK berdasarkan umur aset untuk RE didapatkan 0,71 dibuatkan perhitungan ke profil analisa biaya siklus hidup (LCCA) untuk proses pengadaan reverse engineering didapatkan sesuai tabel 5.

\subsection{Proses Pengadaan Rekondisi}

Asumsi :

1 Mill ada 3 grinding roll $=\mathrm{Rp} .135 .201 .666$.

(PUSHARLIS)

1 Set grinding table = Rp. 115.000.000.

(PUSHARLIS)

Waktu pemesanan $=3$ bulan.

Umur $\quad=5.232 \mathrm{jam}=0,6$ tahun.

Perhitungan disamakan dari 3 alternatif dalam penyebutan KPK berdasarkan umur aset untuk rekondsi didapatkan 2,29 dibuatkan perhitungan ke profil Life Cycle Cost Analysis (LCCA) untuk proses pengadaan rekondisi didapatkan sesuai tabel 6. 


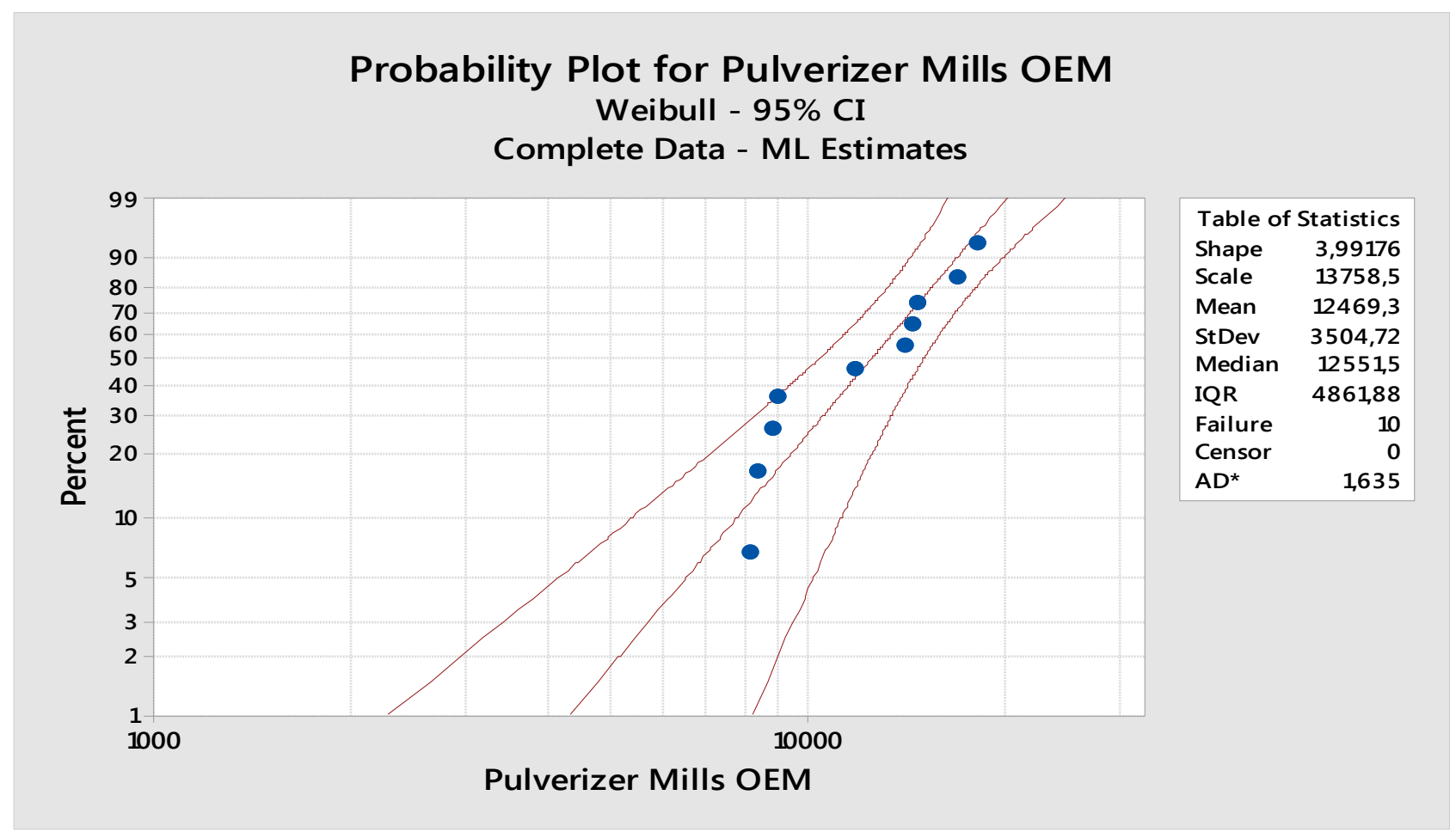

Gambar 3. Grafik $\beta$ dan $\eta$ Pulverizer Mills OEM.

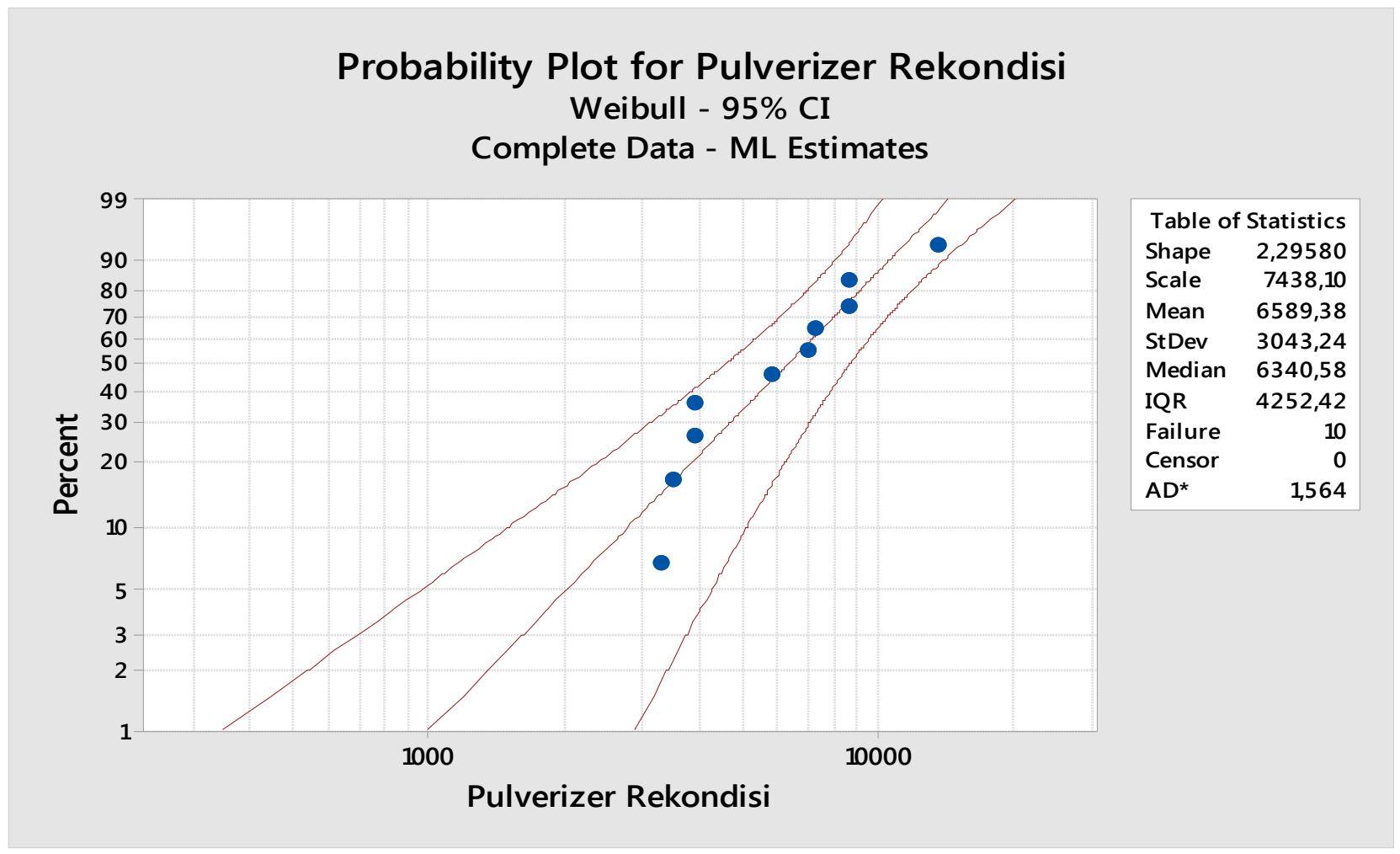

Gambar 4. Grafik $\beta$ dan $\eta$ Rekondisi. 
Tabel 4. NPV Proses Pengadaan Asli Pabrikan (OEM)

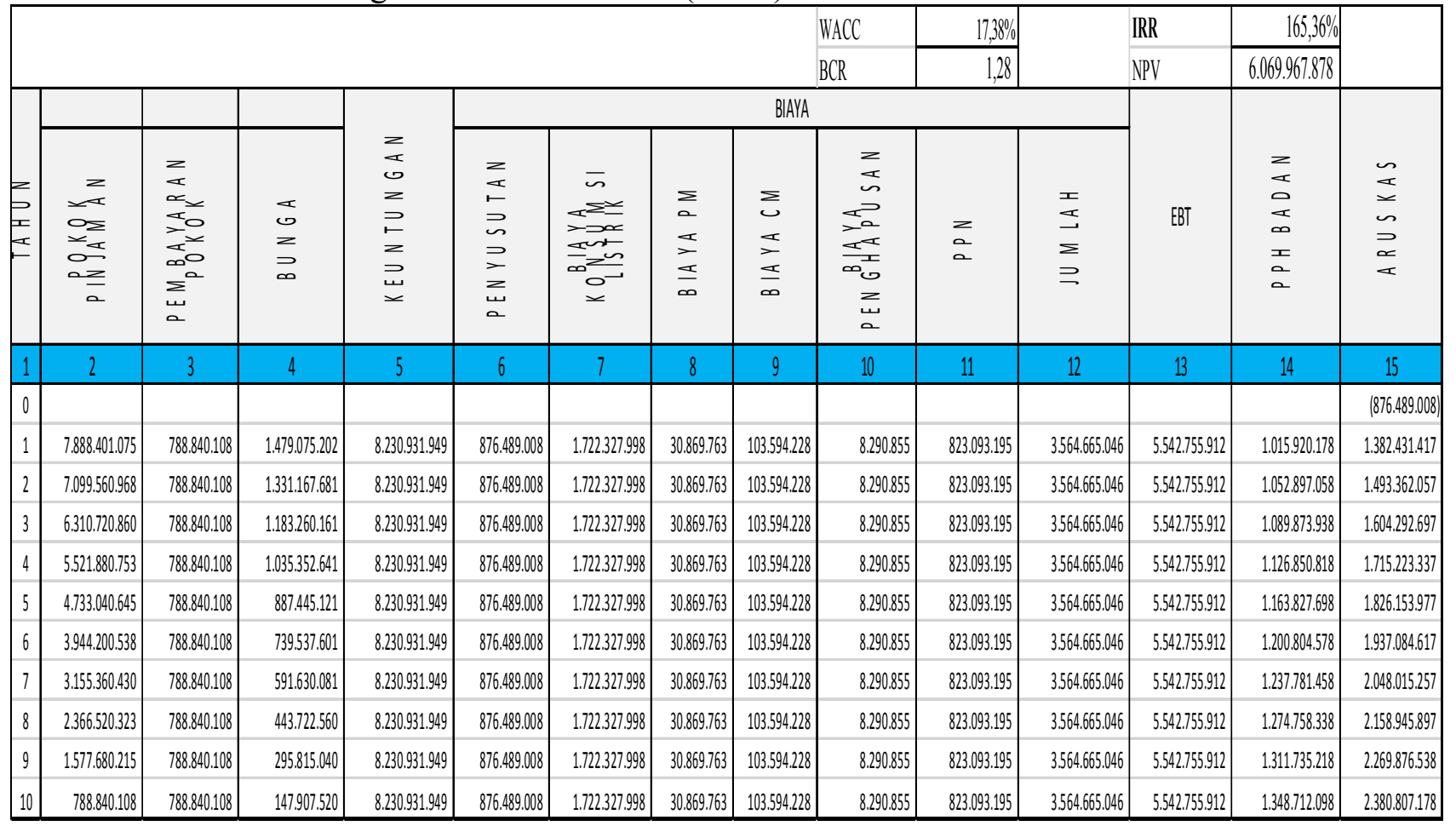

Tabel 5. NPV Proses Pengadaan Non OEM / Reverse Engineering

\begin{tabular}{|c|c|c|c|c|c|c|c|c|c|c|c|c|c|c|}
\hline & & & & & & & & & & $17,38 \%$ & & & $1435,92 \%$ & \\
\hline & & & & & & & & & & 1,76 & & PV & 13.803 .746 .679 & \\
\hline $\begin{array}{l}z \\
z \\
z \\
a\end{array}$ & $\begin{array}{l}z \\
\leq \\
\sum \\
\leq \\
\vdots \\
\vdots \\
a \\
\vdots \\
0 \\
0 \\
0 \\
0\end{array}$ & 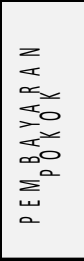 & $\begin{array}{l}x \\
0 \\
2 \\
\equiv \\
\infty\end{array}$ & 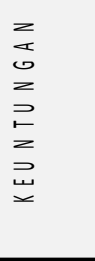 & $\begin{array}{l}z \\
z \\
5 \\
3 \\
2 \\
\geq \\
\geq \\
z \\
z \\
a\end{array}$ & 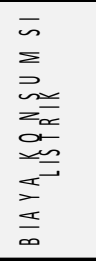 & $\begin{array}{l}\sum \\
a \\
\vdots \\
\vdots \\
\vdots \\
\infty\end{array}$ & $\begin{array}{l}\Sigma \\
\Sigma \\
\Sigma \\
\vdots \\
\infty\end{array}$ & 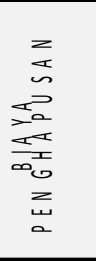 & z & $\begin{array}{l} \pm \\
\pm \\
\equiv \\
\equiv\end{array}$ & EBT & $\begin{array}{l}z \\
a \\
0 \\
0 \\
0 \\
0 \\
\text { I } \\
a \\
a\end{array}$ & 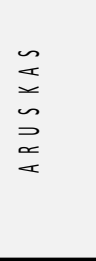 \\
\hline 1 & 2 & 3 & 4 & 5 & 6 & 7 & 8 & 9 & 10 & 11 & 12 & 13 & 14 & 15 \\
\hline 0 & & & & & & & & & & & & & & (290.114.874) \\
\hline 1 & 2.611 .033 .864 & 261.103 .386 & 489.568 .850 & 9.932 .564 .527 & 290.114 .874 & 2.078 .395 .749 & 18.464.499 & 61.964 .048 & 4.959.108 & 993.256 .453 & 3.447 .154 .730 & 6.775 .524 .670 & 1.571 .488 .955 & 4.163.248.606 \\
\hline 2 & 2.349 .930 .478 & 261.103.386 & 440.611 .965 & 9.932 .564 .527 & 290.114 .874 & 2.078 .395 .749 & 18.464 .499 & 61.964 .048 & 4.959.108 & 993.256 .453 & 3.447 .154 .730 & 6.775 .524 .670 & 1.583 .728 .176 & 4.199.966.269 \\
\hline 3 & 2.088 .827 .091 & 261.103.386 & 391.655 .080 & 9.932 .564 .527 & 290.114 .874 & 2.078 .395 .749 & 18.464.499 & 61.964 .048 & 4.959.108 & 993.256 .453 & 3.447 .154 .730 & 6.775 .524 .670 & 1.595.967.398 & 4.236.683.933 \\
\hline 4 & 1.827 .723 .705 & 261.103.386 & 342.698 .195 & 9.932 .564 .527 & 290.114 .874 & 2.078 .395 .749 & 18.464 .499 & 61.964 .048 & 4.559.108 & 993.256 .453 & 3.447 .154 .730 & 6.775 .524 .670 & 1.608 .206 .619 & 4.273.401.597 \\
\hline 5 & 1.566 .620 .318 & 261.103.386 & 293.741.310 & 9.932 .564 .527 & 290.114 .874 & 2.078 .395 .749 & 18.464 .499 & 61.964 .048 & 4.559.108 & 993.256 .453 & 3.447 .154 .730 & 6.775 .524 .670 & 1.620 .45 .840 & 4.310 .119 .260 \\
\hline 6 & 1.305 .516 .932 & 261.103.386 & 244.784 .425 & 9.932 .564 .527 & 290.114 .874 & 2.078.395.749 & 18.466.499 & 61.964 .048 & 4.959.108 & 993.256 .453 & 3.447 .154 .730 & 6.775 .524 .670 & 1.632 .685 .061 & 4.346.836.924 \\
\hline 7 & 1.044 .413 .546 & 261.103.386 & 195.827 .540 & 9.932 .564 .527 & 290.114 .874 & 2.078 .395 .749 & 18.464 .499 & 61.964 .048 & 4.559.108 & 993.256 .453 & 3.447 .154 .730 & 6.775 .524 .670 & 1.644 .924 .283 & 4.383.554.588 \\
\hline 8 & 783.310 .159 & 261.103.386 & 146.870 .655 & 9.932 .564 .527 & 290.114 .874 & 2.078 .395 .749 & 18.464 .499 & 61.964 .048 & 4.559.108 & 993.256 .453 & 3.447 .154 .730 & 6.775 .524 .670 & 1.657 .163 .504 & 4.420.272.252 \\
\hline 9 & 5222.206 .773 & 261.1033.386 & 97.131 .770 & 9.932 .564 .527 & 200.114 .874 & 2.078 .395 .749 & 18.464.499 & 61.964 .048 & 4.959.108 & 993.256 .453 & 3.447 .154 .730 & 6.775 .524 .670 & 1.6699 .902 .725 & 4.456.989.915 \\
\hline 10 & 261.103 .386 & 261.103.386 & 48.956.885 & 9.932 .564 .527 & 290.114.874 & 2.078 .395 .749 & 18.464.499 & 61.964 .048 & 4.959.108 & 993.256 .453 & 3.447 .1547 .730 & 6.775 .524 .670 & 1.681 .641 .946 & 4.493.707.579 \\
\hline
\end{tabular}


Tabel 6. NPV Proses Pengadaan Rekondisi

\begin{tabular}{|c|c|c|c|c|c|c|c|c|c|c|c|c|c|c|}
\hline & & & & & & & & & $\mathrm{ACC}$ & 17,380\% & & & $55,57 \%$ & \\
\hline & & & & & & & & & CR & 1,12 & & V & 12142.212 .743 & \\
\hline & & & & $z$ & & & & BAYA & & & & & & \\
\hline $\begin{array}{l}E \\
E \\
E\end{array}$ & 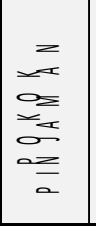 & 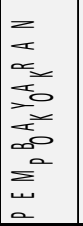 & $\begin{array}{l}\mathbb{I} \\
\Xi \\
z \\
\equiv \\
\infty\end{array}$ & $\begin{array}{l} \pm \\
\Xi \\
z \\
z \\
= \\
z \\
\underline{x}\end{array}$ & $\begin{array}{l}z \\
\leq \\
\leq \\
\equiv \\
\equiv \\
\equiv \\
z \\
z \\
z\end{array}$ & 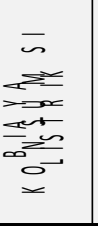 & $\begin{array}{l}\geq \\
\Sigma \\
\pm \\
\Sigma \\
\underline{x} \\
\infty\end{array}$ & $\begin{array}{l}\Sigma \\
心 \\
\Sigma \\
\pm \\
\infty\end{array}$ & 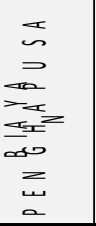 & $\begin{array}{l}z \\
z\end{array}$ & $\begin{array}{l}x \\
\text { 工 } \\
\Sigma \\
\equiv\end{array}$ & EBT & $\begin{array}{l}z \\
\leq \\
0 \\
a \\
\infty \\
x \\
x \\
2 \\
a\end{array}$ & $\begin{array}{l}\approx \\
\simeq \\
\approx \\
\approx \\
\approx\end{array}$ \\
\hline 1 & 2 & 3 & 4 & 5 & 6 & 1 & 8 & 9 & 10 & 11 & 12 & 13 & 14 & 15 \\
\hline 0 & & & & & & & & & & & & & & $\mid 5722.518 .508)$ \\
\hline 1 & 5.152 .666 .576 & 515.266 .5658 & 966.124 .983 & 4.284 .641 .663 & 5725.518 .508 & 8965644.124 & 59.639 .060 & 200.139 .613 & 16.017 .576 & 428.464 .166 & 2.173 .343 .048 & 2.683 .817 .123 & 429.423 .035 & $200.883,3939$ \\
\hline 2 & $4,637,3999.918$ & 515.266 .658 & 8695512.245 & 4.284 .641 .663 & 572.5185508 & 8965564.124 & 59.639 .060 & 200.139 .613 & 160.17576 & 428.464 .166 & $2,173.343 .048$ & 2.683 .817 .123 & 4535.76 .1600 & 272.943 .313 \\
\hline 3 & 4.122 .1333 .261 & 515.266 .658 & 772.899986 & 4.2846464 .663 & 572.5185508 & 8965564.124 & 59.639 .060 & 2001.139 .613 & 16.017576 & 428.464 .166 & 2.173 .343 .048 & 2.6838 .871 .123 & 477.729 .824 & 345.402 .686 \\
\hline 4 & 3.006 .8666003 & 515.266 .658 & 676.287 .488 & 4.284.641.663 & 5725.5185080 & 8965.564.124 & 596.639 .060 & 200139.6913 & 160.17576 & 428.464 .166 & 2.173 .343 .048 & 2.683 .817 .123 & 501.882 .409 & 417.862 .060 \\
\hline 5 & 3.091 .5999 .946 & 515.2666 .558 & 5796774990 & 4.284 .641 .663 & 572518.5088 & 8965644.124 & 59.639 .060 & 200.139 .613 & 16,017576 & 428.464 .166 & 2.1733 .343 .048 & 2.683 .817 .123 & 526.035 .533 & 490,3211434 \\
\hline 6 & 2.576 .333 .288 & 515.266 .658 & 483.062 .929 & 4.284 .641 .663 & 5725185.508 & 8965644.124 & 59.639 .060 & 200.139 .613 & 160.17576 & 428.464 .166 & 2.173 .343 .048 & $26.683 .817,123$ & 550.1886.58 & 56278008088 \\
\hline 7 & 20.061 .0666 .630 & 515.266 .658 & 386.499993 & 4.284 .641 .663 & 572.5185508 & 8965.564 .124 & 59.639 .060 & 200.139 .613 & 160.17576 & 428.464 .166 & 2.173 .343 .048 & 2.683 .817 .123 & 573444.1782 & 635.2001.181 \\
\hline 8 & 1.545 .799 .973 & 515.266 .658 & 289.837 .455 & 4.284 .641 .663 & 572.5185058 & 896.564 .124 & 59.639 .060 & 2001.139 .613 & $16.017,576$ & 428.464 .166 & 2.173 .343 .048 & 2.683 .817 .123 & 5989.494 .907 & 707.699555 \\
\hline 9 & 1.030 .5333 .315 & 515.266 .658 & 193.224.9997 & 4.284 .641 .663 & 5725.518508 & 896.564 .124 & 596.639 .060 & 200139.6913 & $160.017,576$ & 428.464 .166 & 2.173 .343 .048 & 2.683 .817 .123 & 6226.68 .032 & 780.158 .229 \\
\hline 10 & 515.266 .5658 & 515.2666 .558 & 96.612 .498 & 4.284 .641 .663 & 572518.5080 & 896.564 .124 & 59.639 .060 & 200.139 .613 & 160.17576 & 428.464 .166 & 2.173 .343 .048 & $26883.817,123$ & 6468001.156 & 8526.618 .303 \\
\hline
\end{tabular}

\subsection{Analisa Perhitungan}

Dari data diatas dapat digambar 3.profil analisa biaya siklus hidup dari 3 alternatif OEM, RE dan rekondisi sesuai grafik 5.11 dimana biaya investasi paling tinggi pada alternatif OEM sedangkan paling kecil biaya investasi rekondisi namun umur aset paling lama proses reverse engineering dapat mampu beroperasi selama 23,5 bulan/ 2 tahun.

Untuk dapat diperbandingkan dari alternatif diatas maka dibuatkan persamaan Kelipatan Persekutuan terkecil (KPK) dengan disamakan umur aset sampai rusak / failure. Setelah disamakan dan dikalikan hasilnya ke komponen $\mathrm{CI}, \mathrm{CO}, \mathrm{CM}$, CF dan CD setiap alternatif maka hasilnya di total biaya pengeluaran dan pendapatan/ keuntungan avoide cost sehingga didapatkan pilihan yang optimal dari alternatif tersebut didapatkan sesuai gambar 6 .
Dari gambar 6 diatas didapatkan hasil penghematan biaya mencapai 38 Milyar per pulverizer mills selama 10 tahun dengan perbandingan alternatif 2 (proses reverse engineering) dengan alternatif 3 (proses rekondisi). Total biaya - biaya yang tertinggi ada dialternatif 1 (proses OEM) sebesar 64 Milyar dan biaya terkecil alternatif 3 (proses rekondisi) sebesar 38 Milyar namun kehilangan produksi akibat gangguan dan sering pemeliharan sangat berdampak besar terhadap keuntungan bersih menjadi kecil sehingga pendapatan bersi paling kecil diantara alternatif 3 sebesar 4,6 Milyar.

Untuk menganalisa lebih lanjut perlu dibuatkan analisa titik impas (break even analysis) gabungan 3 alternatif terhadap cost benefit menghindari avoide cost dengan total item biaya sesuai gambar 8 . Dimana NPV mulai positif dilakukan dengan cara interpolasi sehigga didapatkan keuntungan 
dengan avoid cost alternatif rekondisi baru minimal diatas X3> $29 \mathrm{Rp} / \mathrm{kWh}$ sedangkan altenatif reverse engineering dengan avoid $\mathrm{X} 2>13 \mathrm{Rp} / \mathrm{kWh}$ sudah mendapatkan ke untungan namun setelah dilakukan penggabungan 3 alternatif didapatkan avoide cost harus $\mathrm{X} 1>24 \mathrm{Rp} / \mathrm{kWh}$ baru mendapatkan keuntungan dari 3 pilihan tersebut.
Untuk lebih jelas lagi dibuatkan analisis sensitivitas tingkat suku bunga terhadap NPV dimana dapat dilihat gambar 8. Dimana NPV mulai positif dilakukan dengan cara interpolasi sehingga tingkat bunga bank maksimal dibawah X3<41\% sedangkan altenatif reverse engineering tingkat bunga bank maksimal dibawah $\mathrm{X} 2<418 \%$ dan alternatif OEM tingkat bunga bank maksimal dibawah X1<74\%.

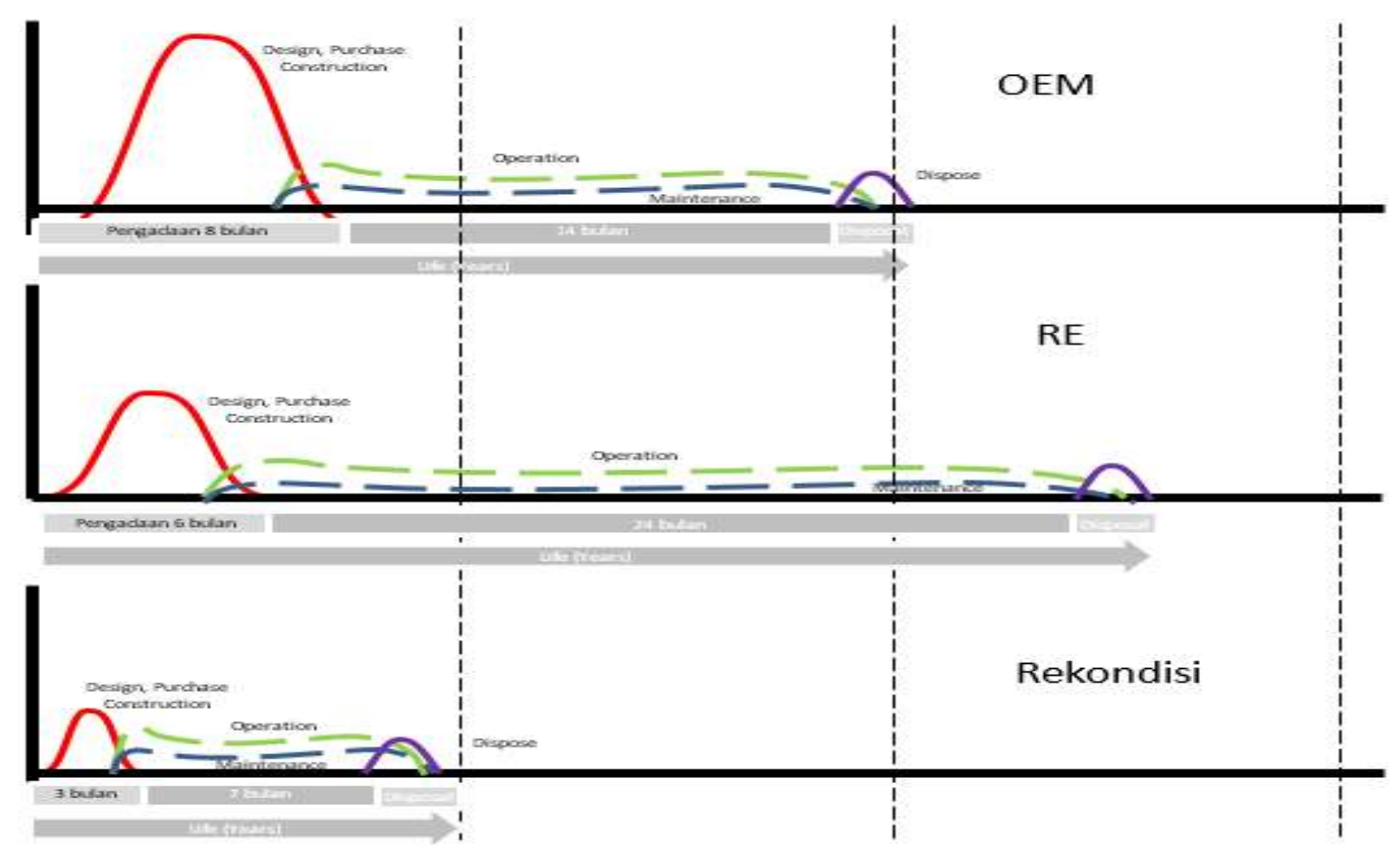

Gambar 5. Grafik Profil Analisa Biaya Siklus Hidup Mills.

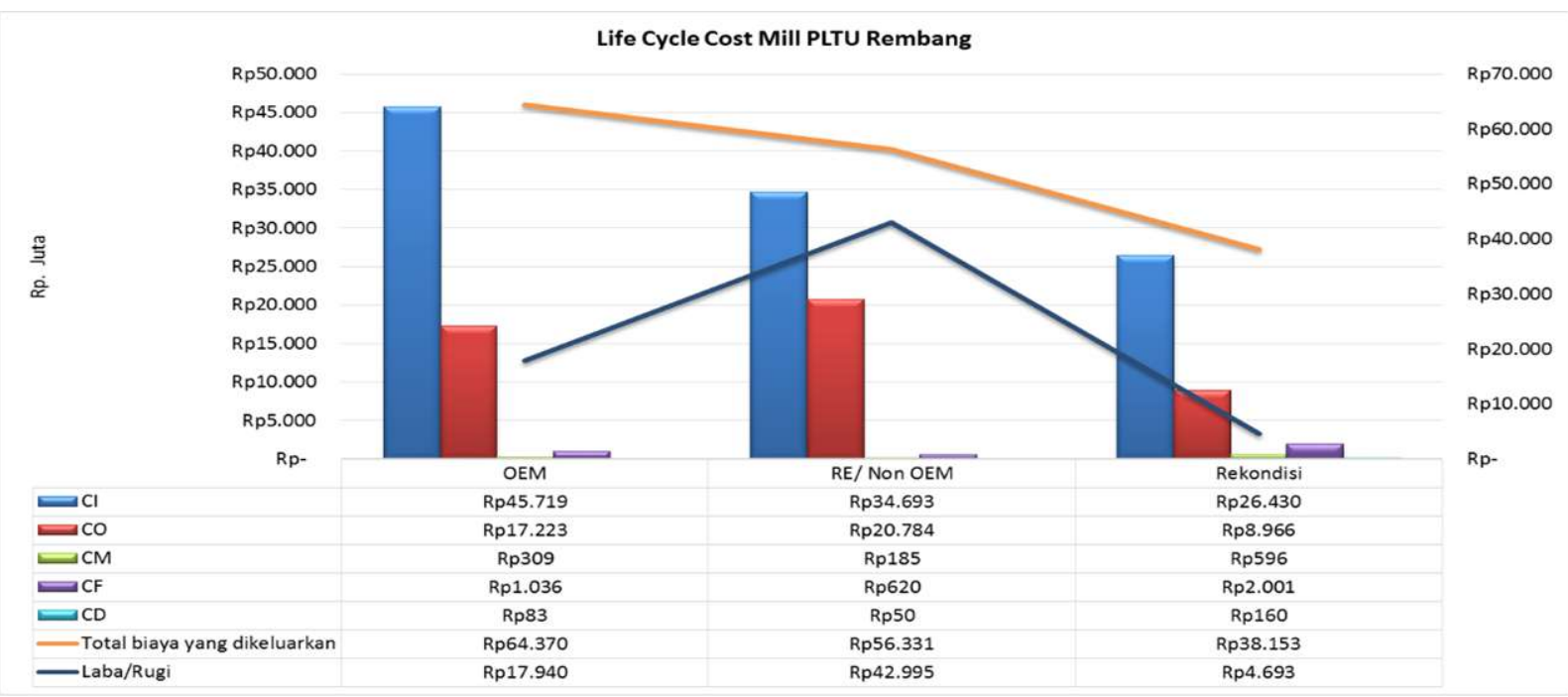

Gambar 6. Grafik Perhitungan Analisa Biaya Siklus Hidup Pulverizer Mills. 


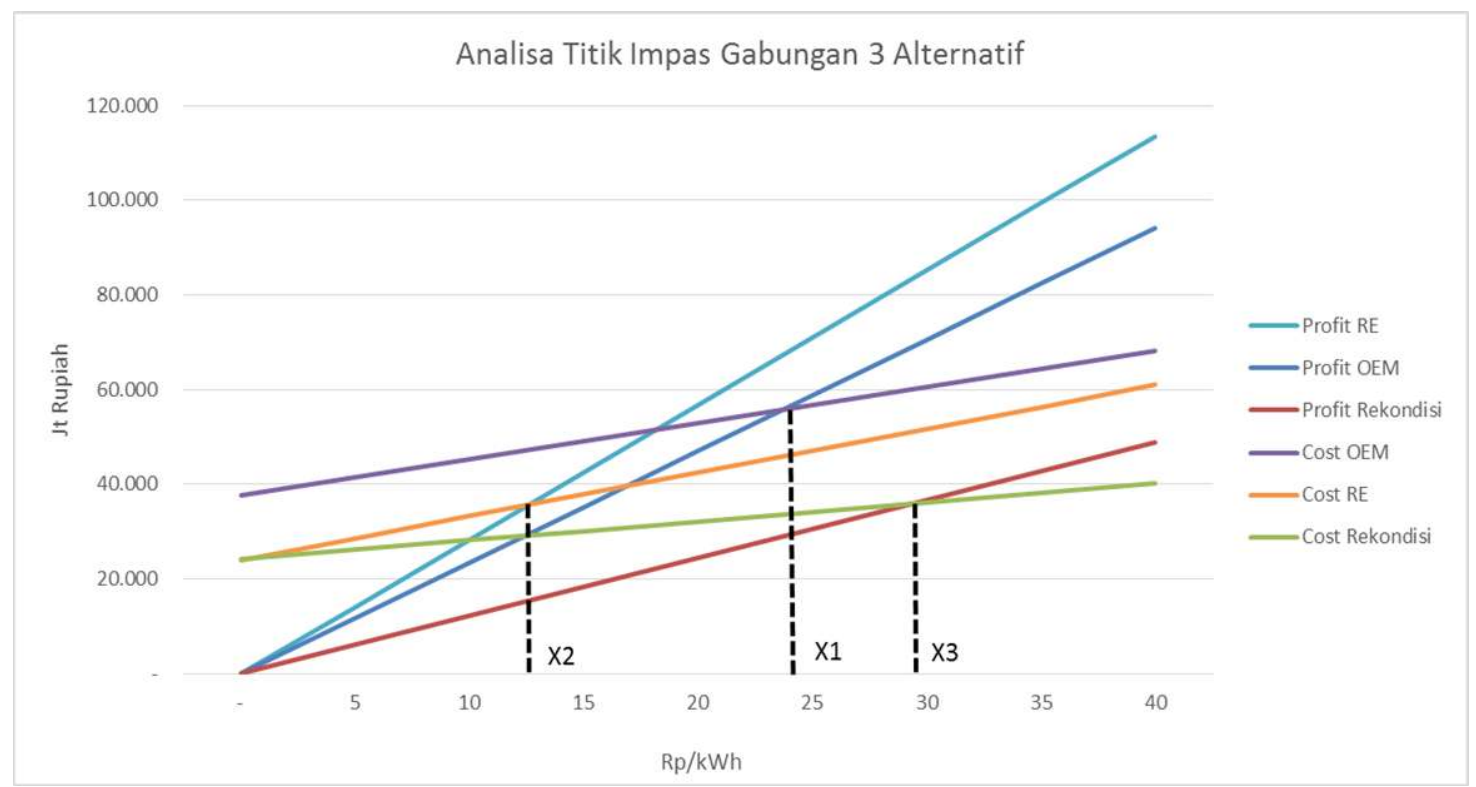

Gambar 7. Grafik Analisa Titik Impas BEP \& Harga Listrik.

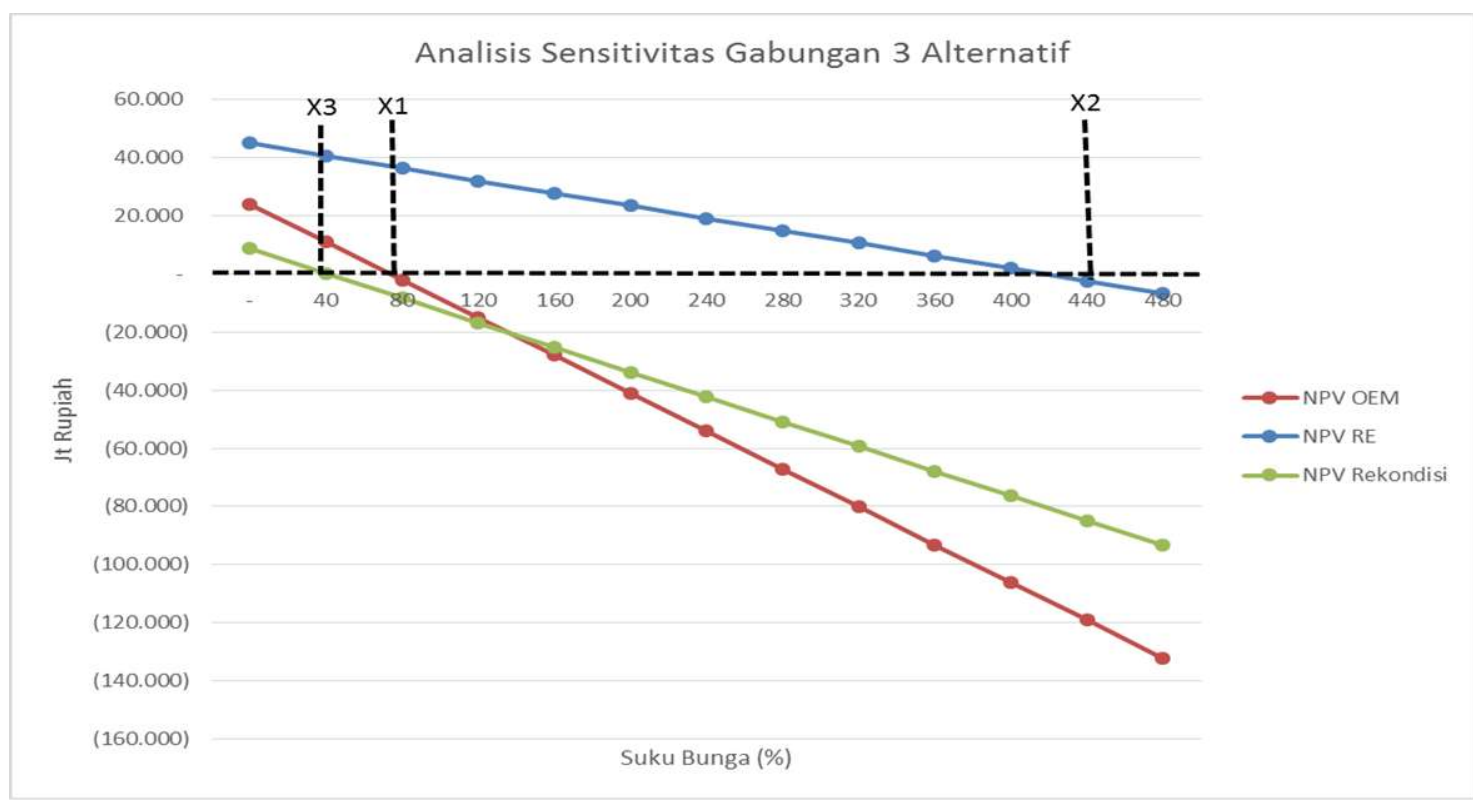

Gambar 8. Grafik Analisis Sensitivitas Gabungan.

\section{KESIMPULAN DAN SARAN}

\subsection{Kesimpulan}

Berdasarkan hasil pengumpulan, pengelolahan data dan analisa data yang telah dilakukan maka dapat diambil kesimpulan sebagai berikut :

1. Dari analisa data secara kualitatif dengan menggunakan simulasi monte carlo umur aset pulverizer mills / mean time to failure (MTTF) proses pengadaan OEM didapatkan selama $10.108 \mathrm{jam} / 1,2$ tahun, proses pengadaan reverse engineering didapatkan selama $16.899 \mathrm{jam} / 2$ tahun sedangakn proses pengadaan rekondisi didapatkan selama $5.232 \mathrm{jam} / 7$ bulan.

2. Dari analisa data secara kualitatif dengan perhitungan pendekatan analisa biaya siklus hidup (LCCA) selama 10 tahun biaya total pengeluaran terkecil didapatkan perhitungan alternatif proses pengadaan rekondisi sebesar 38 Milyar kemudian alternatif proses pengadaan reverse engineering sebesar 56 Milyar dan alternatif proses pengadaan OEM sebesar 64 Milyar. Keuntungan avoide cost tertinggi adalah alternatif proses pengadaan reverse engineering sebesar 99 
Milyar, OEM sebesar 82 Milyar dan Rekondisi sebesar 43 Milyar sehingga laba tertinggi - terendah secara berurutan yaitu alternatif RE, OEM dan Rekonisi sebesar 43 Milyar, 17 Milyar dan 4,6 Milyar dengan perhitungan analisa finansial untuk :
a. OEM NPV 6.069.967.878, IRR $165,3 \%$ dan BCR 1,28.
b. RE NPV 13.803.746.679, IRR $1.435,92 \%$ dan BCR 1,76 .
c. Rekondisi NPV 1.214.212.743, IRR $55,57 \%$ \& BCR 1,12.

3. Dari grafik gabungan alternatif titik impas terhadap avoid cost dengan total biaya didapatkan titik impas minimum benefit cost menghindari avoid cost dari 3 alternatif adalah sebesar $>13 \mathrm{Rp} / \mathrm{kWh}$ (Reverse Engineering), $>24 \quad \mathrm{Rp} / \mathrm{kWh}$ (OEM), dan $>29 \mathrm{Rp} / \mathrm{kWh}$.

4. Dari data perhitungan diatas alternatif proses pengadaan reverse engineering (Alternatif 2) adalah alternatif yang paling optimal dari pada dua alternatif yang ada, sebab dapat menghindari kegagalan, menghindari kehilangan kesempatan produksi dan mengurangi biaya pemeliharaan.

\subsection{Saran}

1. Berdasarkan dari hasil pengolahaan data secara kualitatif, penulis menyarankan agar metode life cycle cost ini dapat digunakan untuk analisis komponen selain Pulverizer mills dengan teori Life Cycle Cost Analysis (LCCA).

2. Manajemen hendaknya mengupdate datadata pendukung yang aktual dalam aplikasi Rapsodi sampai level 3 sehingga didapatkan meprediksi secara mengoptimalkan terkait risiko, cost dan performance.

3. Metode ini masih perlu dilakukan pengembangan lebih lanjut.

\section{DAFTAR PUSTAKA}

Barrett P J, 2001. Life Cycle Costing. Australia National Audit Office.

Herry Nugraha, Zivion O. Silalahi and Ngapili I. Sinisuka, 2016. Maintenance Decision Models for Java-Bali 150-kV Power Transmission Submarine Cable Using RAMS. Power and Energy Technology Systems Journal 10.1109/JPETS.2016.2516944.

I Nyoman Pujawan, 2009. Ekonomi Teknik. Edisi Kedua. Surabaya : Guna Wijaya.

Iwan Agung Firstantara, 2014. Manajemen Aset Fisik Strategis Refleksi Implementasi di PLN UPJB. Edisi Pertama, Yogyakarta : Leutika Prio.

Jianpeng Bian, Xiaoyun Sun, Mingming Wang, Haiqing Zheng, Hui Xing, 2014. Probabilistic Analysis of Life Cycle Cost for Power Transformer. Journal of Power and Energy Engineering, 2, 489-494.

Ngapuli I. Sinisuka \& Herry Nugraha, 2013. Life Cycle Cost Analysis On The Operation Of Power Generation. Journal of Quality in Maintenance engineering, Vol. 19 Iss 1 pp. 5-24

PT PLN (Persero), 2017. Protap Deklarasi Kondisi Pembangkit dan Indeks Kinerja Pembangkit.

Ratna Bhakti P S \& Sudiyono K, 2015. Perancangan Sistem Pemeliharaan Menggunakan Metode Reliability Centered Maintenance (RCM) Pada Pulverizer (Studi Kasus : PLTU Paiton Unit 3). Jurnal Teknik ITS Vol. 6, No. 1 ISSN:2337-3539

Rio Prasetyo Lukodono, Pratika, Rudy Soenoko, 2013. Analisis Penerapan Metode RCM dan MVSM Untuk Meningkatkan Keandalan Pada Sistem Maintenance (Studi Kasus PG.X). Jurnal Rekayasa Mesin Vol.4, No.1 43-52. 
Umi Fitriyani, 2011. Penentuan Waktu Perawatan Pulverizer Menggunakan Metode Reliability Centered Maintenance (RCM) dengan Pendekatan Benefit-Cost Analysis (Study Kasus: PT PJB UP Paiton). Surabaya: Tugas Akhir Teknologi Industri Institut Teknologi Sepuluh November.

Weta Hary W, Abdullah A dan Nurlita G, 2013. Analisis Keandalan Pada Boiler PLTU dengan Menggunakan Metode Failure Mode Effect Analysis (FMEA). Jurnal Teknik POMITS Vol. 1, No.1, 1-6.

Winda Nur Cahyo, 2008. Pendekatan Simulasi Monte Carlo Untuk Pemelihan Alternatif Dengan Decision Tree Pada Nilai Outcome Yang Probabilistik, Teknoin, Valume 13, Nomor 2, 11-17 ISSN:0853-8697. 